\title{
The formation of the modern legal subject and the development of citizenship in Iran between two revolutions (1906-1979)
}

OÑATI SOCIO-LEGAL SERIES VOLUME 10, ISSUE 5 (2020), 1016-1039: HiSTORICAL AND COMPARATIVE MACROSOCIOLOGY OF MIDDLE EASTERN LEGAL SYSTEMS

DOI LINK: HTTPS://DOI.ORG/10.35295/OSLS.IISL/0000-0000-0000-1027

RECEIVED 07 SEPTEMBER 2018, ACCEPTED 08 APRIL 2019

\section{HADI ENAYAT*}

\section{Abstract}

This article explores the formation of the modern legal subject in postconstitutional and Pahlavi Iran (1906-1979) and its relationship to citizenship. It first explores, at an abstract level, the relationship between law, subject-formation and citizenship before looking at the historical and comparative aspects of personhood in the Western and Islamic legal traditions. This forms the backdrop for analysis of the legal reforms triggered by the Constitutional Revolution of 1906, with a particular focus on the civil and penal codes which were promulgated under Reza Shah and the complex and conflicted notions of subjectivity and citizenship which they nurtured. The article will conclude with some observations about the relationship between law, subjectivity and citizenship between the two revolutions and beyond.

\section{Key words}

Citizenship; subjectivity; revolution; legality; civil law; penal law; constitutional; Iran

\section{Resumen}

Este artículo examina la formación del sujeto jurídico moderno en el Irán posconstitucional y en la era de los Pahlaví (1906-1979) y su relación con la ciudadanía. En primer lugar, analiza, en un nivel abstracto, la relación entre derecho, formación de sujeto y ciudadanía; después, se fija en los aspectos históricos y comparativos de la persona en las tradiciones jurídicas occidental e islámica. Esto configura el panorama para el análisis de las reformas jurídicas impulsadas por la Revolución Constitucional de 1906, con especial atención en los códigos civil y penal que fueron promulgados durante el reinado de Reza Pahlaví, y las complejas y conflictivas nociones de

\footnotetext{
* Hadi Enayat is a visiting lecturer at the Aga Khan Centre in London. His book Law, State and Society in Iran: Constitutionalism, Autocracy and Legal Reform 1906-1941 won the biennial Mossadegh Prize in 2013. Contact details: Aga Khan Centre in London, 10 Handyside St, Kings Cross, London N1C 4DN (UK). Email address: enayathadi@gmail.com
} 
subjetividad y ciudadanía que aquéllos alimentaron. El artículo concluye con algunas observaciones sobre la relación entre derecho, subjetividad y ciudadanía entre las dos revoluciones y más allá.

\section{Palabras clave}

Ciudadanía; subjetividad; revolución; legalidad; derecho civil; derecho penal; constitucional; Irán 


\section{Table of contents}

1. Introduction: Law, Subject-Formation and Citizenship ........................................... 1019

2. The "Person" as Legal Subject in Western and Islamic Legal Traditions ................. 1022

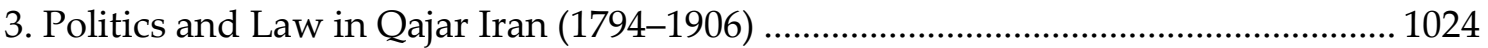

4. The Constitutional Revolution and the Contested Notions of Citizenship .............. 1026

5. The Civil Code and the Unification of the Legal Subject........................................... 1027

6. The Duality of Penal Law and the Carving out of a Margin

of "Insulated Liberalism"

7. Conclusion: The Conflicted Legacies of the Modern Legal Subject

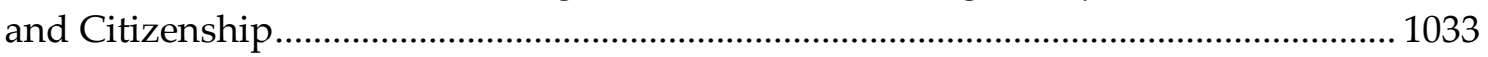

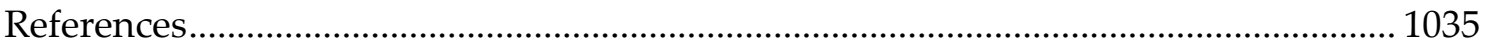




\section{Introduction: Law, Subject-Formation and Citizenship}

What role has law played in modern Iranian society - governed as it has been by a succession of systems that range from the imperial to the Islamic and are strongly authoritarian? This question will be addressed in this paper by looking at the relationship between law, subject-formation and citizenship between the two revolutions of 1906 and 1979 and beyond. By mapping the emergence of the individual person as the main subject of legal rights the paper will explore the problems and possibilities of this process for the emergence of 'citizenship' in modern Iran. We will begin here with the question of the role which law plays in the construction of the modern "subject". Foucault's influential work on power suggests that it can be a "positive" force which is constitutive and performative in that produces the ways in which we live and act in the world. Thus, the exercise of power is not purely repressive but also productive in that it entails reconstructing "subjectivities" (Foucault 1980, De Lagasnerie 2018). ${ }^{1}$ This means that power works "through individuals rather than against them and helps constitute the individual who is at the same time its vehicle" (Garland 1990, p. 138). This process of subject-formation is complex and multifaceted involving a range of economic, educational and medical discourses. When applied to law it implies that the legal order cannot be reduced to a set of constraints acting on each of us externally. To be sure even though many people have no direct contact with the legal system for much of their lives the presence and effects of the law are felt everywhere (Weiner 2013, p. 45). The law thus significantly shapes how we are formed as subjects because how we relate to ourselves and to others is mediated by legal norms and processes. Thus, the legal system does not act on a preformed subject, rather the subject is to a significant extent created inside the legal system and its operations (De Lagasnerie 2018). ${ }^{2}$ The law, in other words, is one of the "sources of the self". ${ }^{3}$

Moreover, being a subject of the law means being subjected to and confronted by "the state's construction of reality and having to live with it" (De Lagasnerie 2018). As a result, the legal subject experiences a certain amount of dispossession, vulnerability and subordination. Because of these radical critiques of law have generally emphasized its functions as an instrument of ideological interpellation, political regimentation and class power in capitalist modernity. But the law is often more contradictory than this and is also a sphere in which the historic gains of collective struggles can be preserved (Khachaturian 2017). Despite its frequent violation, especially in authoritarian states, formal legality can facilitate a certain kind of respect for human agency by offering

\footnotetext{
${ }^{1}$ As Foucault puts it in one of his lectures: “... in thinking of the mechanisms of power, I am thinking rather of its capillary forms of existence, the point where power reaches into the very grain of individuals, touches their bodies, and inserts itself into their actions and attitude, their discourses, learning processes and everyday lives" (Foucault 1980, p. 39).

${ }^{2}$ Note that some readings of Foucault claim that he failed to appreciate the importance of "juridicial power" and instead focused on what he called "disciplinary power". Others have argued that this is a misreading and that Foucault had a subtle understanding of the role of law in modernity and that "law" and "discipline" are not mutually exclusive but interdependent form of power (see Golder and Fitzpatrick 2009, pp. 12-30). ${ }^{3}$ For Foucault modern citizenship featured a double persona, juridicial-legal on the one hand, economic on the other. But as Wendy Brown argues the latter is not derived from the former. The subject of right - what Foucault referred to as homo juridicus - is a creature derived or deduced from state sovereignty not from imagined primary drives or capacities in the human being. In this sense it bears no parallel with the primary drives of homo oeconomicus (Foucault 2008, pp. 292-93, Brown 2015, p. 85).
} 
individuals subject to law an opportunity to express themselves and make arguments based on claims of right (Lee 2007, Rundle 2012, pp. 8-11). But formal legality is nothing without informal reality and the rights enshrined in constitutions and codes are nothing without enforcement (Friedman 1990, p. 11). For this reason, formal legality often invokes cynicism about what Marx called the "deceptive semblance" of its operations (Fine 2002, p. 120). Nevertheless, formal legality is a necessary (though far from sufficient) condition to protect the weak against the strong. This is because legal rights which are recognised in practice but are formally unrecognised in law (as in traditional informal legal systems) are often precarious. "People want to have their rights in black and white, incised in stone as it were; they want them to have formal reality". The demand for rights then has often been a demand for law - that is for the formal recognition of rights (Friedman 1990, p. 11). ${ }^{4}$

In turn the demand for legal rights is often framed in terms of struggles for "citizenship". Studies of citizenship are characterized by a tension between a "minimalist" definition of citizenship as an "an 'institution' mediating rights between the subjects of politics and the polity to which these subjects belong" (Isin and Nyers quoted in Cooper 2018, p. 5) and a "maximalist" definition that insists that citizenship necessarily entails full political participation, equality among all citizens, a range of rights such as free speech and the protection of private property and the rule of law - in short, the premises of Western liberal democracy (Cooper 2018, p. 5). This maximalist conception is a philosophically and historically specific one with roots in the French Revolution and more generally in $18^{\text {th }}$ century Western political thought. But as Frederick Cooper has argued, to assume that citizenship necessarily entails a set list of rights or the sovereignty of "the people" narrows the domain of enquiry and is a case of the scholarly vice of petitio principii ${ }^{5}$ which avoids posing the most critical question: "[W]hat is the relationship between the fact of "belonging" to a political unit and the possibility of making claims on that unit and those who govern it?" (Cooper 2018, p. 5). As Cooper relates:

Might not horizontal relationships of citizens - with each other - put pressure on vertical ones? Might not people who do not benefit from a powerful patron find common cause with people like themselves against the exclusions from which they suffer? If a state is to sustain the allegiance of its citizens, is it in some degree constrained to provide them with security or perhaps mechanisms to insure order, if not improvement, in their lives? When ruling elites concede something to 'their' people might that not then encourage them to take for granted a certain status and possibly ask for more? Might citizenship be contagious, as people see examples of something to gain by attachment and loyalty to a polity? By leaving open the relationship of belonging and rights - and of horizontal and vertical relationships - one can study citizenship beyond the limited context of post-1789 Europe and its extensions, and also understand

\footnotetext{
${ }^{4}$ Note that Critical Legal Theorists have generally argued against this position. For Duncan Kennedy, for example, the indeterminacy of the law is closely related to its formality. As Kennedy argues the application of rules "indirectly brings about the agreed distribution" of outcomes, and ultimately, power (Kennedy 1973, p. 386). Whilst the thesis of indeterminacy has been useful in understanding the influence of politics on law it has also been shown to be overstated and problematic. Critical responses to the CLS position on legal indeterminacy include Kress (1989), Greenwalt (1990) and Coleman and Leiter (1993).

${ }^{5}$ When the conclusions of an argument are built into its premises - sometimes referred to as "begging the question".
} 
more of the dynamics of claim-making (...) and the range of political possibilities that process has opened up, and sometimes shut down. (Cooper 2018, p. 6)

As Cooper suggests at the end of the quote above, citizenship is deeply paradoxical as it lies at the nexus between "constituent power" (the popular will, protests, political participation) and "constituted power" (constitutions, laws, proceduralism). Étienne Balibar has tried to capture this paradox and challenge the binary of "citizen" and "subject" in terms of the composite notion of the "citizen-subject" who can be both subversive and submissive because the citizen is both subject of and subject to power (Balibar 2017, pp. 26-29, Isin 2017, pp. 514-515). Thus, too categorical a distinction between the "citizen" as bearer of rights and the "subject" as right-less member of a political unit excludes the grey area in between which characterizes struggles for citizenship in many historical and contemporary contexts (Cooper 2018, p. 6).

Focusing on legal reform in early twentieth century Iran is a productive way to explore these contradictions and more broadly to grapple with the complex relationship between law and the development of citizenship in a non-Western authoritarian polity. This is because the place of "law" (qanun) in the ideology of the 1906 Constitutionalist Movement is in many ways unique (Katouzian 2003, p. 84). The original demand of the political movement which culminated in the 1906 Iranian Constitutional Revolution was for a "house of justice" ('edalatkhaneh). In the discourse of late nineteenth-century Iranian reformers a "house of justice" meant a system of state courts which would function on the basis of law, not the arbitrary whim of the monarch or the prince-governors of Iran's far-flung provinces. Reformist intellectuals in the nineteenth century such as Malkam Khan and Mostashar al-Dawleh identified "law" (qanun), which they viewed as an essential prerequisite of progress and civilization, as the key institution missing from their societies. Drawing on older Iranian ideas, the justice necessary for civilization was posited as the "rule of law" and Iranian modernists foregrounded the cultivation of the individual as the means through which justice, increasingly posited as constitutional government, could be achieved (Kia 2015, p. 146). Their discourse was adopted by reformers in the last decades of the nineteenth century, and at the turn of the twentieth century by the constitutionalist movement. This rendered "legality", in a normative sense at least, an important component of Iranian political modernity and makes the Iranian case particularly interesting in terms of understanding the relationship between law and ideology and how different conceptions of legality found expression in the process of institution-building. The 1906 revolution triggered a process of institutional transformation and secularization that witnessed the emergence of new concepts and practices of government, law and citizenship. This process was driven by a struggle between three conflicting though not mutually exclusive conceptions of legality and the social classes behind them: Islamic (with its emphasis on clericalism and the shari'a), liberal (with its emphasis on separation of powers, civil and political rights and property rights) and étatiste (legal positivism, executive domination of the judiciary and military courts). By the end of Reza Shah's reign, the étatiste conception had won the day and the Islamic and liberal conceptions were marginalized though never completely nullified.

But while the legal reforms of the post-constitutional and Pahlavi period were driven by an authoritarian logic and the rule of law was very weak the reforms also contributed to developing what Farzin Vahdat calls "inchoate subjectivity" (Vahdat 2015, p. 84). This is a notion of subjectivity which is contradictory and incomplete but nevertheless crucial 
in that it transformed the social psychology of significant sections of Iranian society and nurtured a sense of rights and therefore citizenship - a notion of empowered personhood with agency to make claims based on rights -. Undoubtedly this notion of citizenship was underdeveloped and partial but it nevertheless helped motivate large numbers of Iranians to mobilise in various agitations during the course of postconstitutionalist and the Pahlavi periods culminating in the 1979 revolution. Vahdat makes this argument with reference to the educational, military and bureaucratic reforms under the Pahlavis and argues that these should be seen as integrally related to each other in nurturing a contradictory form of agentification (Vahdat 2015, pp. 87-90). ${ }^{6}$ I would argue that the legal reforms of this period were also an important factor in this respect and focusing on them can complement Vahdat's analysis of the development of subjectivity in modern Iran. Whilst the legal reforms were primarily about building a strong centralised state, in a limited form, they also created opportunities for Iranians to assert their rights as citizens. Moreover, whilst constitutionalist paeans to equality and freedom were largely violated they helped to generate a political imaginary which has inspired social movements in Iran to the present day. Before turning to Iran we will first briefly explore the concept of the legal subject in historical and comparative perspective. This will hopefully contextualise our discussion of the transition triggered by the Iranian constitutional revolution and the formation of the modern legal subject in Iran more clearly.

\section{The "Person" as Legal Subject in Western and Islamic Legal Traditions}

The meaning of "legal personality" is ambiguous and has never been fully resolved in psychology, philosophy or jurisprudence. In colloquial terms a "person" is simply a human being but in legal terms it refers to a subject endowed with rights and duties. This formulation suggests that there is a distinction between the everyday understanding of what it means to be a person - that all humans are persons and all persons are humans - and the legal metaphor "person" which may exclude some humans and include some non-humans - the most notable example being the corporation endowed with legal personality (What We Talk About... 2001). In the modern Western legal tradition it is the Kantian conception of a "person" endowed with autonomy, will, responsibility and intentionality (the notion of subjectivity dismantled by Foucault) that is central to the operation of civil and penal law (Dupret 2004, p. 15). The Kantian subject is a legal fiction without which the concept of criminal responsibility could not function. Moreover, without it we would "merely" be right-less individuals or what Giorgio Agamben refers to as homo sacer ("bare life") who are deprived from the protection of the law and can be treated as objects, as was the case with slaves, women,

\footnotetext{
${ }^{6}$ Vahdat emphasises the contradictory nature of these reforms in relation to subjectivity. For example, in connection with the military reforms he writes: "[T]he conscript army in Iran of the Reza Shah period was largely a rudimentary (and coercive as well as brutal) institution of modern-nation building. Nevertheless, as a basic modern institution, it was a crucial first step in the formation of agency, albeit quite crude and primitive, that affected significant segments of the populace in Iran. In the absence of wide-scale education for larger number of people, the army of Reza Shah was the only institution that imparted a modicum of discipline, education, and a convoluted and contradictory sense of self-reliance that was at the same time grounded in obedience and humiliation" (Vahdat 2015, p. 87).
} 
and children in ancient Greece and Rome and as still is the case with asylum seekers, illegal migrants and state-less people (Agamben 1998, p. 181, Gaaker 2016, p. 288).

In the Western legal tradition the notion of a "person" as the subject of law has a long history going back to Roman law in which legal personality, family, property, treaty and tort were the building blocks of the Codex Justinianus (Gaakeer 2016, p. 288). The contractual and individualistic nature of feudalism in the West is also a common theme in Western political thought from Montesquieu to Weber to modern writers, such as Michael Mann (S. Zubaida, 2016. The Legacy of Islam: Shari'a, Individual Rights and Communal Rights. Unpublished conference paper, on file with author). But despite these historical antecedents the establishment of the individual person as the central "jural unit" of adjudicatory processes is by no means natural and developed "only after a long historical process of dialectical negation and synthesis" (Weiner 2013, p. 3). It is only after the legal system has transcended notions of clan, family responsibility, gender and slavery that all individuals (potentially at least) become recognised as persons (Rorty 1976, p. 309). Mark Weiner has contrasted this concept of legal personality with that which existed under what he calls "the rule of the clan" (Weiner 2013). This form of governance exists on a spectrum ranging from stateless societies, known as segmentary lineage systems, to modern societies in which a weak state struggles to contain the forces of clannism. Clannism can also persist in developed centralised states (Weiner 2013, p. 48). Generally speaking though this kind of governance is characterised by a radically fragmented and decentralised constitutional structure which makes the extended family, suffused with a culture of group honour and shame, the basic unit of legal empowerment. In this scenario, to use the language of the nineteenth-century legal historian Henry Maine, the individual's legal rights and obligations depend significantly on his or her "status" within the extended family or kin group. Personal autonomy is radically circumscribed and subordinated to the power of the corporate group. (Weiner 2013, p.10). Weiner argues that modern individualism and autonomy could develop only once central governments were powerful enough to check the power of extended families and other corporate groups. That is only once they could supplant the rule of the clan with a socio-legal order animated by what Maine called the principle of "contract" (Weiner 2013, p. 10). ${ }^{7}$ A great deal is won and lost in this process: solidarity diminishes as a value but the potential for individual autonomy is amplified.

What is the understanding of the "person" and legal "subject" in the Islamic tradition? In Islamic thought we find some historical antecedents to the notion of a "person" particularly in falsafa in which are found speculations on "the mind" (ruh) or "the soul" (nafs) (Nachi 2004, p. 57). The thought of Fakr al-din Razi in particular ruminates on personal pronouns and one can detect in his writing "traits that precede in the word shakhs the modern idea of a 'person'" (Nachi 2004, p. 58). Shahab Ahmed has argued that questions about the meaning and constitution of the "self" have been central to Islamic discourses for centuries. These have included debates about the authority of aql (reason) versus naql (transmission) as a means of knowledge in falsafa, about the validity of

\footnotetext{
7 This is what Weiner calls the "paradox of individualism". It is a common belief that liberty exists only when the state is absent or weak and that individual freedom flourishes in inverse proportion to the strength and scope of the state. But this misunderstands the source of liberty and Weiner argues, in a Durkheimian mode, that whilst states can be despotic and totalitarian a healthy democratic state dedicated to the public interest is essential to nurturing individual liberty (Weiner 2013, p. 6).
} 
altered states of consciousness as a means of knowing in Sufism and about the constitution of human agency and responsibility in debates about qada and qadar (predestination and free-will). As Ahmed relates: "the Muslim predicament of hermeneutical engagement with Revelation is directly productive of a trajectory of Self-interrogation, Self-contemplation, Self-affirmation, Self-articulation, and Self-action as means to meaning in terms of Islam (Ahmed 2016, p. 330). ${ }^{8}$ Individual personality is even more pronounced in Islamic jurisprudence. The shari'a, both in theory and in practice, was highly individualistic. This is because, in contrast to traditional pagan doctrines the uncompromising monotheism of Islam (tawhid) encouraged believers to think of themselves as individuals with moral responsibility rather than as members of particular groups or tribes. Moreover, the absence of the concept of a church as the mystical "body of Christ" that stood between the individual and God through whom alone salvation is possible "militated against the creation of institutions such as the medieval Western city or trading company where the group transcended that of the individual" (Ruthven 2000, p. 88). Thus, the transactional elements of the shari'a (muamalat) recognised no corporate entities (with the notable exceptions of waqf) and conceived the individual as the legal subject of contract: property, sale, hire, labour and even marriage (S. Zubaida, 2016. The Legacy of Islam: Shari'a, Individual Rights and Communal Rights. Unpublished conference paper, on file with author). The individual is also the subject of penal law, except in the case of diyeh (blood-money), in which the kin group could be held responsible for the compensation. But as Zubaida emphasises the sphere of private legal transactions and personal status were distinct from issues of the relation of individuals and communities to the political and religious authorities, which were only nominally controlled by the shari'a, and varied across time and space. For the most part politics took place in relation to collective and corporate units of neighbourhood, village, tribe, religious community, Sufi order and guilds (broadly what Weiner refers to as "clannism"). These were often units of taxation and collective responsibility to the authorities, empowering their corporate leaders and notables over their members. Thus "notwithstanding the individualising thrust of the shari'a, social and political organisation continued, like in most pre-modern formations, to be corporate, tribal and communal" (S. Zubaida, 2016. The Legacy of Islam: Shari'a, Individual Rights and Communal Rights. Unpublished conference paper, on file with author).

\section{Politics and Law in Qajar Iran (1794-1906)}

With the theoretical and historical sketch above in mind we can now turn our focus to Qajar Iran in the nineteenth century. The Qajar monarchy displayed many of the features of classical patrimonialism identified by Weber. The kingdom was an extension of the shah's household and subject to his personal authority. There was no distinction between property and office and offices were often sold as a source of revenue and patronage by the shah and his officials. Nor was there a standing army which meant that the shah had to rely on often unpredictable tribal levies (Arjomand 1989, pp. 25-6). The Qajar monarchy is usefully characterized in Michael Mann's well-known formulation of

\footnotetext{
8 As what he calls a "cogito moment" in Islamic history Ahmed cites Ibn Sina's thought experiment of the "Floating Man" by which the Muslim philosopher sought to demonstrate that "the existence of the soul is a distinct identity from the body (...) which he [the person] knows through his self-consciousness" (Ahmed 2016, pp. 330-331).
} 
the nature of power in pre-modern empires (Mann 1986, pp. 109-136). The state was "despotically strong" in that there was no formal law or constitution to limit its power. The normative framework of the shari'a was an important factor in measuring the legitimacy of the rulers in the eyes of the populace, but did not generate institutional or legal checks on the power of the shah which was in practice arbitrary and sometimes brutal. At the same time the Qajar state was "infrastructurally weak," particularly weak because it lacked the military and administrative capacity to exercise its power beyond a very limited social and geographical range. This weakness was primarily due to a lack of a standing army. This combination meant that for more than a century the Qajars ruled through a "parcellized" system of prince-governors, pursuing a policy of divide and rule both at the heart of government and on its periphery, a strategy which for several decades was successful in a country composed of a myriad of tribal, religious and ethnic groups. Martin has argued that the basic social contract in Qajar Iran was achieved through negotiation on the basis of acknowledged rights and obligations. The shah had the duty to protect Shi'i Islam and the community of believers. In exchange it was his right to expect his subjects (ro'yat) to observe their duties and recognize his authority (Martin 2005, pp. 10-12). In terms of the legal scene nineteenth-century Iran was characterized by legal pluralism. A number of different actors were involved in the administration of justice including clerics, state officials, local elders, landowners and tribal leaders. Most disputes were resolved informally and according to local custom within families, guilds and other corporate groups, as well as village and tribal communities. The religious minorities, principally Jews, Christians, and Zoroastrians, also had autonomy in resolving intra-communal disputes and in matters of personal status were subject to their own religious law (Floor 1983, p. 117).

Thus, the Qajar state displayed the kind of decentralised and fragmented constitutional structure identified by Weiner as "clannism". Traditional politics was one of factions of ruling elites and clerics competing and battling for power and resources. Other members of the population were only involved as supporters of one faction or another in networks of patronage and control (S. Zubaida, 2016. The Legacy of Islam: Shari'a, Individual Rights and Communal Rights. Unpublished conference paper, on file with author). Moreover, individual's legal rights and obligations depended significantly on his or her place within the kin group - his or her "status" within the extended family, tribe or clan - and as a result, personal autonomy was radically circumscribed, especially for women.

Why was "law" such a central goal in the 1906 Constitutional Movement? The legal system under the Qajars was often the subject of complaints by ordinary people who in their petitions to the Shah would complain of the arbitrary and often brutal nature of the justice especially of the orf courts which were often presided over by local governors. Land and property disputes and the arbitrary seizure of property was also a common theme in these complaints. These were often exacerbated by the practice of ahkam-e mo'arez (contradictory rulings by mojtahids which carried equal legal validity). Although the practice of ahkam-e mo'arez introduced an element of flexibility into the legal system it meant that disputes could drag on for years and was the cause of numerous complaints in Qajar Iran, especially among merchants for whom predictability and consistency was vital (Enayat 2013, p. 37). The fragmentation and general dysfunctionality of the system led to several attempts at reform most notably under Amir Kabir (1807-1852) and Sepahsalar (1871-1873). These attempts largely failed however, partly due to the 
weakness and corruption of the Qajar dynasty and partly because of the opposition of local governors and ulama who generally opposed any attempts to undermine their power. This failure to reform helps to explain the centrality of "law" in the discourse of the Constitutional Revolution. By the eve of the revolution most of the classes of urban society - the intellectuals, merchants, guildsmen, reformist bureaucrats and the ulama had united under the banner of qanun (law) and 'edalatkhaneh (house of justice).

\section{The Constitutional Revolution and the Contested Notions of Citizenship}

The victory of the Constitutional Movement led to the promulgation of the Constitution and the Supplementary Law in 1907 that involved conceptual shifts which, however weakly instituted at the time, were to have far-reaching implications. Firstly, the establishment of a parliament (majles) meant that for the first time there was a lawmaking institution independent of both the will of the ruler and the shari'a. Secondly, we see the beginnings in this period of the "juridification" of the state: the increasing formalization and writing of regulations defining public office and the rules of governance (Poggi 1978, p. 105). A concept of public law emerged (hoquq-e 'omumi), which was distinct from the shari'a, from custom, and from the tradition of mazalem justice since it had a raison d'etre other than the will of the ruler. Indeed, the ruler was to be himself bound by law. ${ }^{9}$ Thirdly, concomitant with the "juridification" of the state, the judicial clauses of the 1907 Supplementary Law marked the first steps in the "etatization" of the law and the introduction of novel legal procedures derived from European models (Zubaida 2003, p. 125).

The Supplementary Law of the Constitution passed in 1907 after a great deal of political mobilization and debate enshrined a number of civil and political rights. Among them were individual liberty of the citizens, religious freedom, freedom of expression assembly and organization, protection of property rights and equality of all (male) citizens before the law. Notably the Supplementary Law of 1907 also implicitly banned the ownership of another person though slavery was not abolished outright until 1928 (Martin 2005, p. 165). But these rights were hedged in with limitations defined by the shari'a and the authority of the ulama (Afary 1996, p. 108). As a result, there was a great deal of confusion and ambiguity over the law during this period of revolutionary transition. A number of court cases, such as the famous "Daughters of Quchan" as well as the trial of the Muslim murderers of the Zoroastrian merchant Feraydun Zartoshti, which took place during the Constitutional Revolution illustrate the contested notions of legal rights and citizenship during this period. These cases were highly dramatized in the emergent national press and were followed closely because they were enacting some of the central demands of the constitutional movement and were constitutive of the emergent meaning of citizenship (Najmabadi 1998, p. 117). ${ }^{10}$ These court cases were part of that process, at times muddled and confused. There was ambiguity, contestation and confusion over the meaning of many of the constitutional and legal principles which were invoked - especially the meaning of "equality before the law". For some it meant applying the shari'a more stringently, regardless of rank and status, while retaining

\footnotetext{
${ }^{9}$ See Gheissari 1998 (pp. 70-71) on the concept of public law in Iran.

${ }^{10}$ For analysis of the "Daughters of Quchan" and the trial of the murderers of Feraydun Zartoshti as well as a number of others which took place in 1907 see Najmabadi (1998, p. 128), Enayat (2013, pp. 72-79).
} 
traditional shari'a distinctions of religion and gender. Citizens could be equal before the law but they were not necessarily equal in the law. For others "equality before the law" meant the abolition of religious distinctions and was inspired by Enlightenment principles of universal human rights drawn from the French Revolution.

Despite these contestations and confusions, by establishing formal equality before the law the Supplementary Law of the Constitution (1907) had begun a process of the gradual unification of the legal subject which would allow Iranians to imagine themselves as individual citizens who all had the same rights and duties irrespective of class, religion, ethnicity, gender or region (though there were important exclusions and exceptions to this - especially in the area of gender and ethnicity). Departing from the traditional axiom that people were dissimilar because they were distinguished by birth, occupation, residence, or religion, the legal reforms gradually established the formal legal equality of all Iranian citizens. The abolition of these distinctions entailed a new social imaginary and concept of personhood. A new type of individual had to be imagined who existed, by way of a legal fiction, in abstraction from political, economic, familial, tribal and religious ties. Consequently, an individual who claimed his or her rights simultaneously affirmed the equal rights of all (Holmes 1993, p. 230, Herzog 2018, p. 189). Of course, this formal equality was to be frequently violated but the contradiction between formal principles and concrete existence has been one which has been exploited by social movements of different stripes ever since including women, ethnic and religious minorities and the poor and working classes.

\section{The Civil Code and the Unification of the Legal Subject}

The following will discuss how the unification of the legal subject was advanced with the promulgation of the civil code. With the establishment of the Pahlavi Monarchy in 1921 Reza Shah engaged in an authoritarian program of state-building and centralization funded by increasing oil revenues. This involved a range of reforms from military to financial and administrative to legal and judicial. Central to the aim of legal and judicial reform was the promulgation of new civil and penal codes. These codifications had begun earlier in the immediate post-constitutionalist period but were weakly instituted and largely opposed and undermined by the ulama. Under Reza Shah legal reform became central to his project of building a powerful centralized bureaucratic state and he appointed Ali Akbar Khan Davar (1885-1937) - whose ideological outlook was the quintessential expression of étatiste authoritarian legality - as the minister of justice tasked with implementing these reforms. Civil law was codified in three volumes: the first in 1928 on property and contracts, and the next two much later, in February 1935 (on persons), and October 1935 (on evidence for substantiation of claims). The codification of civil law meant that the law's basic focus or "jural unit" became more squarely based on the individual rather than the family, clan or religious group as it had often been under the traditional legal system in which law was largely group or community based. Moreover, the civil code initiated three unifications fundamental to the emergence of legal modernity in Iran. The first was the unification of the legal subject, allowing Iranians to imagine themselves as equal citizens who carried the same rights and duties. As we have seen this had been enshrined in Article 8 of the Supplementary Law to the Constitution though in vague terms which were clarified further in the civil code. The code protected the legal rights of all residents of the country, including 
foreigners. Thus Articles 956-975 of volume 2 clearly state that each citizen is possessed of inalienable rights which no one can violate. In matters of personal status foreign residents were to be subject to the laws of their own countries (Art. 964) and the same rights were granted to non-Muslim Iranians whose religions are recognized by the state (Christianity, Judaism, and Zoroastrianism). Book 2 of the civil code maintained the patriarchal provisions of Shi'i figh which gave men and male guardians rights over women in the area of marriage and divorce. These provisions were reformed with the introduction of the Family Protection Law (FPL) of 1967 which gave women more equal rights in marriage and divorce. Crucially women were now granted the right to divorce (talaq) under certain listed conditions. Previously this right had to be negotiated by the wife and, in effect, her family which rarely happened in practice. The FPL achieved this by means of procedural devices thus avoiding an open conflict with Shi'i figh (MirHosseini 2008, p. 220). By the time the FPL was passed this was the only sphere of Iranian law which was subject to the shari'a. Talal Asad has argued that the restriction and codification of the shari'a to this sphere of "personal status law" (hoquq-e ahval-e shakhsiye) - a category derived from the French civil law tradition - was in itself a "secular formula for privatising 'religion' and prepared the ground for the selfgoverning subject" (Asad 2003, p. 228). Asad argues that this constitutes a profound "transmutation" of the shari'a which is now stripped of its political authority and confined to the private domain. State law is deployed to construct a different kind of category in the law - namely, "family law" - in order to constitute a new subject, the "private" subject. Through the family, the "individual is physically and morally reproduced and has his or her primary formation as a "private being'" (Asad 2003, p. 227). As Asad notes in his discussion of the work of the Egyptian jurist Hamid Zaki the concept of personal status law refers to the "ensemble of judicial institutions that define the human person independent of his wealth, obligations and transactions". This he notes is an abstraction which subverts the traditional shari'a categorization of personhood which relies squarely on the categories of male, female, free-man and slave which are "essential to the legal interpretation of the human body, intention and agency" (Asad 2004, p. 231).

The second unification, closely intertwined with the first, was towards national unification. The uniformity of the law made it an instrument of nation-state building since it undermined not only local differences in tribal and customary law (although custom was recognized in areas in which the code was silent), but also differences in interpretation and helped to forge a nation with a shared identity congruent with the boundaries of the Iranian nation-state. This was thus a vital instrument in encouraging Iranians to imagine themselves as citizens of a common public living under the same laws. The code made the law more legible for bureaucrats and administrators and the uniformity of rules and regulations made it easier for officials to administer justice, provide law and order and collect revenue. It was in this sense both an expression of étatiste and liberal legality.

The third unification was of various rights over things into "property rights" (hoquq-e malekiyat). Historically, land tenure arrangements bequeathed by the various conquests and dynastic changes were a confusing tapestry of Islamic legal principles, state design, customary law, tribal law, and informal practice, forming a "web of tenures" regime of 
land ownership (Sait and Lim 2006, p. 57). ${ }^{11}$ All this meant that there were complex, and sometimes contradictory, land tenure arrangements which were contingent and subject to competing jurisdictions. Property rights were often poorly defined and disputed with the arbitrary power of members of the state apparatus and landowning classes usually prevailing over other claims. As we have seen this uncertainty was exacerbated by the practice of ahkam-e mo'arez (contradictory rulings). New land registration laws which were promulgated between 1911 and 1928 along with the codification of land law in the civil code, was part of a process facilitating a transition towards a capitalist economy based more squarely on individualized private ownership. This was concomitant with Iran's growing integration into the world economy and the shift to cash crops and the concentration of land into large private holdings, often at the expense of the customary rights of peasants and tribesmen (Cronin 2007, p. 151). Indeed, the new system was exploited by the upper and middle classes at the expense of the peasantry leading to the expansion of private ownership of land. By granting individual leaders and local merchants absolute ownership rights to land that peasants had previously had access to it facilitated the "juridicial modernization of patriarchal structures in society" (Sharabi 1988, p, 55).

But again, contradictions abounded. As early as the 1920s and 30s there is evidence that peasants also used the courts because the law could be an equalizing force in an unequal society. The rules of evidence in a court meant that a positive outcome for a local strongman was not a foregone conclusion. Stephanie Cronin observes that the new land laws raised the political consciousness of some elements of the rural population (Cronin 2007 , p. 151). The growing contact between villages and towns during the 1920s led to the dissemination of reformist ideas in the countryside through organizations like the Setareh-ye Bakhtiyari which formulated a comprehensive program of political reform, including proposals for land reform and the rights of peasants and workers which was distributed as a pamphlet. Publications like these were sometimes read out in markets for the benefit of illiterate peasants who had come to sell their produce. These helped disseminate new ideas about freedom and equality. Greater awareness of their legal rights also meant that in some instances villagers and tribesmen tried to use legal methods to redress their grievances (Cronin 2007, p. 162). ${ }^{12}$ Generally, very little is known about the extent to which peasants and tribesmen used the new courts and how successful they were in their claims. We cannot assume, however, that the new legal institutions were simply imposed on a bewildered rural population who, due to their alien nature either rejected them violently or accepted them passively. As Mundy and Smith observe in their study of land registration in Ottoman Syria during the nineteenth century:

\footnotetext{
${ }^{11}$ Nomani lists eight categories in recent centuries: common peasants land; state lands; conditional land rights (iqta or tuyul); unconditional land rights (soyurqal), crown lands, private lands including large landed estates as well as small peasant properties; awqaf and tribal pastures (quoted in Najmabadi 1987, p. 43).

12 Cronin cites the complaints of the great landowning Hamadani family Qarazoglu In 1933 these landowners told a British official that their peasants were "completely out of hand, and appeal to the police and the law courts at every turn whenever the landlord attempts to assert his rights or declines to sanction some extravagant improvement". For more examples and analyses of peasants using the courts to make claims over land see Cronin (2007, p. 162).
} 
Property in land is constructed at the articulation of three moments: the law as text and interpretive tradition; the administration of law by government institutions wherein a regional elite comes together with government employees appointed from above; and lastly, the translation and negotiation of legal categories by actors in productive systems [peasants and villagers] where right is generated, in part by forces which are independent of the first two moments. (Mundy and Smith 2007, p. 7)

How these three moments of law and property rights were articulated and "translated" in rural Iran during the twentieth century is an area ripe for research. We noted in the introduction that although law is primarily an instrument of the powerful and educated classes this does not prevent subaltern groups from sometimes turning it to their advantage. As Martha Mundy and Richard Suarez Smith observe, state administrators and landed elites cannot simply impose law on a village as if it were a tabula rasa and in order to understand the mediation of state law and subaltern notions of property rights "we need to consider not only the techniques of registration and the character of the administration but also how the registration related to the genesis of right from below" (Mundy and Smith 2007, p. 7).

\section{The Duality of Penal Law and the Carving out of a Margin of "Insulated Liberalism"}

As we have, seen a major goal of the constitutionalist movement was the replacement of arbitrary despotism with the rule of law. The establishment of these criminal due process rights was one of the central goals of constitutionalist reformers as in the traditional system penal law which was largely administered by local governors under urfi jurisdiction was highly arbitrary and often brutal. In 1912 a criminal procedure code established a number of due process rights in law, including provisions for the protection of detainees against abuses of power by police and other state authorities. The 1912 code also included the right to legal counsel. As in other civil law systems based on the French model there was no writ of habeas corpus that allowed unlimited access to the courts to challenge the legality of detention. However, there were a number of provisions to protect detainees. Article 124 stipulated that no-one could be detained for more than 24 hours except by the order of an investigating judge in accordance with the law, and that a defendant must be informed within 24 hours of the nature of his offense. Furthermore, detainees had the right to challenge the legality of their detention by (i) petitioning the investigative judge prior to referring the case to the court; (ii) petitioning the court after referral and, (iii) filing an appeal after conviction.

The codification of substantive criminal law was more difficult and took place in stages between 1917 and 1926. Although the traditional Islamic penal code, consisting of hudud, qesas and tazir, was not always applied in the traditional legal system the symbolic and religious import of these laws meant that reform was met by considerable opposition from sections of the conservative ulama (Enayat 2013, pp. 105-110). But secularization of the penal code was a priority for Reza Shah as it was vital to the abrogation of the muchhated capitulations and the restoration of sovereignty to the Iranian government. ${ }^{13}$ Thus

\footnotetext{
${ }^{13}$ Reza Shah's support for the modernization and expansion of the judiciary was intimately bound up with a drive for national sovereignty central to which was the abrogation of the capitulations. The capitulations in Iran dated back to the Russo-Iranian Treaty of Turkomanchai concluded after a Russian military victory in 1828. Britain acquired similar privileges by the 1841 Anglo-Iranian Commercial Treaty and these were
} 
it was pushed through and in 1926 a secular penal code, an adaptation of the 1810 French Penal Code, was promulgated. Under the new code murder was decisively defined as a public offense dealt with by the state as opposed to a private offense to be dealt with by qesas or diyeh and there was no provision for the application of shari'a law on theft. Moreover, the first ten chapters of the new penal code were based on principles drawn from Western criminal jurisprudence: non-retroactivity, aggravating or mitigating circumstances, suspension of sentences, re-offending, the "non-accumulation rule,"14 amnesty, prerogative of mercy, and rehabilitation (Matine-Daftary 1930, p. 175). Although the constitution had guaranteed the separation of powers and the independence of the judiciary, arbitrary justice meted out by state officials and local governors continued to be a common complaint. The penal code attempted to deal with this problem in two articles. Article 130 stipulated that public civil servants who do not belong to the judiciary, whether they be governors or deputy governors, civil servants belonging to the police or to the constabulary who interfere in cases which come under the jurisdiction of ordinary courts would be dismissed and punished by a two to threemonth prison sentence. Article 193 stipulated that any governor or deputy governor, any other civil servant or private citizen who arrests, detains or illegally confines people without an order from the competent authorities, or explicit authorization in law, would be punished with a three-year prison sentence and forfeit their right to hold office (Matine-Daftary 1930, pp. 176-177).

How did the criminal courts work in practice? Whilst a substantial "thick" rule of law in this area was no more than a chimera under the Pahlavi autocracy a "thinner" procedural rule of law began to emerge. As in other legal systems in authoritarian contexts like Nazi Germany, Spain under Franco and Chile under Pinochet the Iranian case also suggests that it is possible to set up "firewalls" between different sectors of a legal system and that alongside the military courts and arbitrary killings we also see an increasing adherence to due process in ordinary criminal cases (Stephenson 2006, p. 199). ${ }^{15}$ This meant that there were military courts for political trials and ordinary civil and political courts for everybody else. In the former politics trumped over law and in the latter law generally ruled. The increasing use of military courts suggests that the mainstream judiciary could not be trusted to deal with political dissidents according to the wishes of the government. Thus, a measure of what Tamer Moustafa (2008) refers to (in connection with Egypt under Mubarak) as "insulated liberalism" emerged in the legal system in which due process was largely respected for ordinary citizens whilst

soon extended to other Western powers in a series of treaties which included "most favored nation" clauses. Under this regime legal disputes between Iranian and foreign nationals were heard jointly by courts consisting of consuls and representatives of a department of the Ministry of Foreign Affairs known as the kargozari (Zirinsky 2003, pp. 81-99).

${ }^{14}$ Namely, where a person has committed several offenses, consecutive sentences are not imposed and the court pronounces the severest of the penalties available for one of the individual offenses (see The Council of Europe French-English Legal Dictionary).

${ }^{15}$ See Enayat (2013 pp. 156-161) for more examples and analysis of the criminal justice system under Reza Shah. 
dealing with political opponents in military courts or simply through "disappearances" (Moustafa 2008). ${ }^{16}$

Clearly defects remained in the criminal justice system, which continued to be the subject of criticism by Western observers in the 1970s (Baldwin 1973, pp. 492-504, Power 1975, pp. 277-292). Judges were poorly paid and police corruption remained a problem, especially in the rural areas where there were few if any lawyers. ${ }^{17}$ Overall, however, evidence from court-reports (which is fragmentary and limited) shows that the rule of law in ordinary criminal cases was partially instituted and the rights of defendants and detainees were reasonably well protected. The death penalty was only rarely applied to ordinary criminals and the incarceration rate was relatively low (compared with most of the period of the Islamic Republic). ${ }^{18}$

These trends were driven by a culture of liberal legality that was developing in the legal profession which had managed to maintain its independence after 1955 and produced a number of highly skilled lawyers committed to the rule of law (Butler and Levasseur 1976, pp. 19-22). Indeed, the modern "legal field" (consisting of courts, law schools, law reviews) was largely created by "revolutionary lawyers" who had participated in the constitutional revolution and then had worked in various capacities in the modern legal profession. These included Mostapha Adl (1882-1950), Ahmad Kasravi (1890-1946), Mohammad Ali Forughi (1877-1942), Mohammad Mossadeq (1882-1967) and Ahmad Matine-Daftary (1897-1971). They believed in an independent judiciary, impartial court hearings, uniform legal procedures and laws that were clearly framed, publicly proclaimed and impartially enforced. They also wanted to ban torture and cruel punishments, institute checks on the police and saw punishment as a form of deterrence rather than revenge. These men were committed to building a law-based state even if they often saw the construction of a powerful modern state as the priority over democracy or rights and were thus willing to work with Reza Shah. But as they understood these objectives were not necessarily contradictory: only a powerful centralized state could protect individual rights against local strongmen and religious majorities. Consequently, some of the reforms, for example, the introduction of codified criminal and civil law or even the institutionalization of the procedure of appeals, could be viewed both as enhancing rights and as part of the process of centralizing state power. ${ }^{19}$ These observations once again highlight the paradoxical nature of law as both

\footnotetext{
${ }^{16}$ It should be noted that Moustafa is using the concept of "insulated liberalism" to refer to the judiciary as check on executive power during the early 2000s in Egypt whereas here it is being used to refer to as procedural fairness and the institution of criminal rule of law rights.

${ }^{17}$ In 1973 there were only around 3,500 lawyers in Iran (one for every 10000 people compared with one for every 650 in the US at the time). The shortage outside Tehran was particularly acute. For example there were only around 100 in the whole of Fars province and in the city of Shahrud there was said to be one lawyer in a town of 50,000 inhabitants (Power 1975, 281).

18 Based on the permanent prison population, the incarceration rate in 1978, just before the Islamic Revolution, was 25 per 100,000 (Madani 2006); in the 2000s it averaged 230 per 100,000. In 2004-2005, according to a United Nations report, the incarceration rate for the permanent and transient prison population together "represents 490 prisoners per 100,000 of the population, which places the country among the six countries of the world with the highest incarceration rates" (United Nations Office on Drugs and Crime 2007).

${ }_{19}$ Martin Shapiro explains that "a 'right' of appeal is a mechanism providing an independent flow of information to the top on the field performance of administrative subordinates." This may explain why authoritarian regimes who have little regard for civil liberties often preserve the right of appeal. In this way,
} 
an instrument of state power and domination and, at the same time, a restraint upon the state and a defense against tyranny.

\section{Conclusion: The Conflicted Legacies of the Modern Legal Subject and Citizenship}

How did the formation of the modern legal subject relate to citizenship during the period under consideration? Legal reform was an expression of the "Dialectic of Enlightenment" of the Constitutional Movement of 1906 and embodied the contradictory meanings and impulses behind the call for "Law" in that revolution (Gheissari 2016). As we have seen, the reforms of the post constitutionalist and Pahlavi period were primarily driven by an étatiste logic of state-building and power, as well as by the increasing incorporation of Iran into the capitalist world economy, especially from the 1930s onwards. As a result, legal modernization was often painful because it involved dispossession and submission to the power of the new bureaucratic state and its coercive apparatus. From this perspective, making the individual the main subject of rights could be seen as part of the political rationality of an authoritarian rentier state which created atomized juridicial subjects so that it could dominate them more effectively. But the empowerment of the individual as legal subject also undermined what we have identified as "clannism" by loosening communal and patriarchal bonds and thus creating agential possibilities for many Iranians especially for women. Legal individualism and the codification and increasing homogenization of the law also allowed Iranians to imagine themselves as equal citizens who were part of the same public realm. ${ }^{20}$ Moreover, the partial realization of the rule of law - what has been referred to above as "insulated liberalism" - at the level of ordinary civil and criminal law helped to create a measure of social trust which encouraged people to forge bonds with people outside their immediate clan group and to interact with the wider society of citizen-strangers. ${ }^{21}$ Thus, legal individualism paradoxically helped to generate a kind of solidarity beyond the immediate clan-group and the beginnings of the transition from gemeinschaft to gesellschaft. This suggests that juridicial subjectivity is not by definition atomizing and can potentially be redirected towards more collectivist and egalitarian ends (Khachaturian 2017). Moreover, the reforms were also an expression of the liberal legacy of 1906 Constitutionalist Revolution and were often designed and adjudicated by "revolutionary lawyers" who had participated in that movement. Thus, they had an

\footnotetext{
as Shapiro explains, courts play fundamental political functions by acting as avenues "for the upward flow of information and for the downward flow of commands." (Shapiro 2008, p. 140). The process of appeals was important in centralizing the power of the state in eighteenth-century France (Madsen and Dezalay 2002, p. 196).

${ }^{20}$ Once again, this feature of legal modernity had a "dark-side". Homogenization in the name of "equality before the law" was accompanied by a discourse of Iranian nationalism which glorified Iran's Aryan identity and demonised other ethnic groups especially Arabs. It was thus a factor which undermined a pluralistic and inclusive notion of citizenship. This tension between legal equality and nationalism however is a feature of the nation-state in general - even those informed by civic paradigms of nationalism - though it is clearly more acute in authoritarian ethno-national states.

${ }^{21}$ As Yamagishi (2018) argues on the basis of a comparative study of various countries the rule of law can generate societal trust and allow people to seek opportunities and relationships beyond their primary communities. By contrast the absence of a well-functioning legal system reinforces the "rule of the clan".
} 
equality-expanding impulse behind them which gradually extended more legal rights to subaltern groups such as women and peasants and (some) minorities. ${ }^{22}$

Indeed, the emphasis on "law" in the Constitutional Revolution led to the development of a vibrant legal rights discourse and increased legal consciousness in the public domain. From the 1930s onwards, academic journals, official publications and the media jointly contributed to the propagation of legal knowledge, offering legal counsel in advice columns or reporting typical court cases to spread the idea of citizen's legal rights. Iranians were now interpellated as "citizens" endowed with an equal set of civil and political rights rather than "subjects" of the shah existing in a hierarchical "society of orders" in which the individual was firmly subordinated to the social group. Whilst formal citizenship and the rights it entailed did not prevent the human rights abuses of the Pahlavi state, it allowed Iranians to view themselves as public citizens and thus recognize the discrepancies between the law and the absence of legal rights. This was a vital step in nurturing a form of subjectivity, personhood and agency which contributed to the political consciousness of significant sections of Iranian society, especially the modern middle class, though it was a current which was beginning to run through more and more of the strata of Iranian society by the 1970s (though citizenship, for men at least, was also evident in earlier periods such as the democratic interregnum of 19411953).

This form of subjectivity was incomplete and contradictory as it encouraged both submission and opposition to the Pahlavi autocracy. Moreover, it was undermined by the powerful discourse of romantic Iranian nationalism which meant that ethnic minorities (especially Arabs and Kurds) continued to face state discrimination. This no doubt strengthened patriarchal structures and the "rule of the clan" for people from these groups who were compelled to rely on their primary communities for protection. Indeed, the limits of the discourse of constitutional rights and formal legality generated by the mashrutiyat became clearer towards the end of Mohammad Reza Shah's rule when it was increasingly coopted by the state (Randjbar-Daemi 2016). This discourse was nevertheless a dialectical condition of possibility - a learning process born out of struggle and ultimately disillusion - for the emergence of more insurgent modalities of subjectivity and citizenship informed by leftist and Islamist ideologies which were to animate the 1979 revolution such as the "Karbala Paradigm" and Ali Shariati's notion of a religiously-mediated subjectivity..$^{23}$

This would eventually usher in an Islamic Republic based on a radically different conception of law and citizenship but one characterized by its own set of contradictions:

\footnotetext{
${ }^{22}$ Studies of criminal due process rights have shown that members of traditionally disadvantaged groups have been among the chief beneficiaries of these rights. This may be because criminal due process rights are procedural rather than substantive so their enforcement does not require a radical change in the balance of power in society or in the redistribution of wealth (Hirschl 2004, p. 109).

${ }^{23}$ In the Shi' $i$ tradition the oppression and martyrdom of the household of Ali, the son-in-law, and, from the Shi' $i$ perspective, the legitimate successor to the Prophet, has been mourned for centuries. The mourning for these events has usually oscillated between quetism and activism, resignation and protest "During the revolution, the latter more action-oriented aspect of the paradigm became dominant as it was vigorously promoted by the Islamic revolutionaries" (Vahdat 2015, p. 92). Shariati's notion of a religiously mediated subjectivity was a Shi'i version of imago dei which was founded, on the one hand, in a deep belief in human autonomy and free-will and, on the other, on a tawhidi worldview based on the fusion of God, humanity and nature (Saffari 2017, p. 102).
} 
a hybrid republican-theocratic state which has facilitated a greater degree of political participation and social citizenship ${ }^{24}$ than the pre-revolutionary era but one in which the rule of law was in many ways weakened and religious minorities (especially Bahai's and Sufis) and women more oppressed - though women have clawed some of their rights back over time. Moreover, the margin of liberal legality previously established has largely been destroyed. The Islamization of the penal code which has seen the enforcement of brutal hudud punishments - mainly in the first ten years after the revolution and more sporadically since then - is the most striking manifestation of this. Furthermore, the legal profession - once the bastion of liberal legalism inspired by the legacy of the mashrutiyat and later on by Mohamad Mossadeq who gave its independence in 1953 shortly before he was deposed - has been increasingly colonized by the state and lost much of its independence (Nayerri 2012, Künkler 2017, Banakar and Ziaee 2018, pp. 4-7). But the memory of the constitutionalist movement and the discourse of civil rights it generated did not simply disappear after the revolution. This suggests that citizenship is not a linear nor a single-stage process though contrary to $\mathrm{T}$. H Marshall's influential thesis about the sequential logic of citizenship rights - first civil, then political and later social rights - the development of citizenship in modern Iran has taken a different route characterized by ruptures and discontinuities whose outcomes are still uncertain..$^{25}$ Nevertheless, as Vahdat has argued, the hard lessons learnt from the revolutionary excesses during the first ten years of the Islamic Republic has led to the emergence of a more developed form of "intersubjectivity" amongst Iranians. "This is one in which the actor is not only aware of her or his own subjectivity, but acknowledges the same for everyone else: a sine qua non for the development and preservation of democratic institutions" (Vahdat 2015, p. 90). This was particularly evident in the dovume khordad movement during the Khatami Presidency (1997-2005) and the Green Movement of 2009 both of which witnessed a more inclusive concept of citizenship as well as calls for the rule of law, civil rights, women's rights and democracy and at times invoked the Constitutional Revolution of 1906 as the founding moment of this narrative of political liberation.

\section{References}

Afary, J., 1996. The Iranian Constitutional Revolution: Grassroots Democracy, Social Democracy, and the Origins of Feminism. New York: Columbia University Press.

Agamben, G., 1998. Homo Sacer: Sovereign Power and Bare Life. Trans.: D. Heller-Roazen. Redwood City: Stanford University Press.

Ahmed, S., 2016. What is Islam? The Importance of Being Islamic. Princeton University Press.

Arjomand, S.A., 1989. The Turban for the Crown: The Islamic Revolution in Iran. Oxford University Press.

\footnotetext{
${ }^{24}$ On social citizenship and welfare rights under the Islamic Republic see Harris 2017.

${ }^{25}$ We should note that Marshall did not argue that there was an inevitable progression from civil to political to social rights and that he saw the acquisition of rights as a contingent and never-ending struggle (Bellamy 2008, p. 49).
} 
Asad, T., 2003. Formations of the Secular: Christianity, Islam, Modernity. Redwood City: Stanford University Press.

Baldwin, G.B., 1973. The Legal System of Iran. International Lawyer, 7/2, pp. 492-504.

Balibar, E., 2017. Citizen-Subject: Foundations for Political Anthropology. Trans.: S. Miller.

New York: Fordham University Press.

Banakar, R., and Ziaee, K., 2018. The Life of the Law in the Islamic Republic. Iranian Studies [online], first published 26 June. Available from:

https://doi.org/10.1080/00210862.2018.1467266 [Accessed 8 April 2019].

Bellamy, R., 2008. Citizenship: A Very Short Introduction. Oxford University Press.

Brown, W., 2015. Undoing the Demos: Neoliberalism's Stealth Revolution. New York: Zone Books.

Butler, W.J., and Levasseur, G., 1976. Human Rights and the Legal System in Iran [online]. Report. Geneva: International Commission of Jurists. Available from: https://www.icj.org/wp-content/uploads/1976/01/Iran-human-righst-and-thelegal-system-thematic-report-1976-eng.pdf [Accessed 8 April 2019].

Coleman, J.L., and Leiter, B., 1993. Determinacy, Objectivity, and Authority. University of Pennsylvania Law Review [online], 142(2), pp. 549-637. Available from: https://scholarship.law.upenn.edu/penn law review/vol142/iss2/8 [Accessed 8 April 2019].

Cooper, F., 2018. Citizenship, Inequality and Difference: Historical Perspectives. Princeton University Press.

Cronin, S., 2007. Resisting the New State: The Rural Poor, Land and Modernity in Iran, 1921-1941. In: S. Cronin, ed., Subalterns and Protest: History from Below in the Middle East and North Africa. London: Routledge, pp. 141-171.

De Lagasnerie, G., 2018. Judge and Punish: The Penal State on Trial. Redwood City: Stanford University Press.

Dupret, B., 2004. The Person and the Law: Contingency, Individuation and the Subject of the Law. In: B. Dupret, ed., Standing Trial: Law and the Person in the Modern Middle East. London: I.B. Tauris, pp. 9-39.

Enayat, H., 2013. Law, State and Society in Modern Iran: Constitutionalism, Autocracy and Legal Reform 1906-1941. New York: Palgrave Macmillan.

Fine, B., 2002. Democracy and the Rule of Law: Marx's Critique of the Legal Form. Caldwell: The Blackburn Press.

Floor, W., 1983. Changes and Developments in the Judicial System of Qajar Persia (1800-1925). In: C.E. Bosworth and C. Hillenbrand, eds., Qajar Iran. Political, Social and Cultural Change 1800-1925. Edinburgh University Press, pp. 113-147.

Foucault, M. (with C. Gordon, ed.), 1980. Power/Knowledge: Selected Interviews and Other Writings 1972-77. Trans.: C. Gordon et al. New York: Pantheon Books.

Foucault, M., 2008. The Birth of Biopolitics: Lectures at the Collège de France. Trans.: G. Burchell. New York: Palgrave Macmillan. 
Friedman, L., 1990. The Republic of Choice: Law, Authority and Culture. Cambridge, MA: Harvard University Press.

Gaakeer, J., 2016. Sua cuique persona? A Note on the Fiction of Legal Personhood and a Reflection on Interdisciplinary Consequences. Law and Literature [online], 28(3), pp. 287-317. Available from: https://doi.org/10.1080/1535685X.2016.1232920 [Accessed 8 April 2019].

Garland, D., 1990. Punishment and Modern Society: A Study in Social Theory. Oxford University Press.

Gheissari, A., 1998. Iranian Intellectuals in the Twentieth Century. Austin: University of Texas Press.

Gheissari, A., 2016. Iran's Dialectic of the Enlightenment: Constitutional Experience, Transregional Connections and Conflicting Narratives of Modernity. In: A.M. Ansari, ed., Iran's Constitutional Revolution of 1906: Narratives of the Enlightenment. London: Gingko Library.

Golder, B., and Fitzpatrick, P., 2009. Foucault's Law. London: Routledge.

Greenawalt, H., 1990. How Law Can be Determinate. UCLA Law Review, 38, pp. 1-86.

Harris, K., 2017. A Social Revolution: Politics and the Welfare State in Iran. Berkeley: University of California Press.

Herzog, T., 2018. A Short History of European Law: The Last Two and a Half Millenia. Cambridge, MA: Harvard University Press.

Hirschl, R., 2004. Towards Juristocracy: The Origins and Consequences of the New Constitutionalism. Cambridge, MA: Harvard University Press.

Holmes, S., 1993. The Anatomy of Illiberalism. Cambridge, MA: Harvard University Press.

Holmes, S., 1995. Passions and Constraint: On the Theory of Liberal Democracy. Chicago University Press.

Isin, E., 2017. Citizenship Studies and the Middle East. In: R. Meijer and N. Butenschøn, eds., The Crisis of Citizenship in the Arab World. Leiden/Boston: Brill, pp. 511-534.

Katouzian, H., 2003. Iranian Politics and History: The Dialectic of State and Society. London: Routledge.

Kennedy, D., 1973. Legal Formality. The Journal of Legal Studies, 2(2), pp. 351-397.

Khachaturian, R., 2017. Poulantzas and the Juridicial Constitution of the Subject. Verso Blog [online], 7 November. Available from:

https://www.versobooks.com/blogs/3473-poulantzas-and-the-juridicalconstitution-of-the-subject [Accessed 8 April 2019].

Kia, M., 2015. Moral Refinement and Manhood in Persian [online]. In: M. Pernau et al., Civilising Emotions: Concepts in Nineteenth Century Asia and Europe. Oxford University Press, pp. 146-149. Available from: https://doi.org/10.1093/acprof:oso/9780198745532.003.0008 [Accessed 8 April 2019]. 
Kress, K., 1989. Legal Indeterminacy. California Law Review [online], 77(2), pp. 283-337. Available from: https://doi.org/10.2307/3480606 [Accessed 8 April 2019].

Künkler, M., 2017. Rule of Law or Rule by Law? Iran's Bar Association as a pawn in Islamic-republican contestations. In: S. Tellenbach and T. Hanstein, eds., Beiträge zum Islamischen Recht XII. Reihe: Leipziger Beiträge zur Orientforschung, pp. 133153.

Lee, C.K., 2007. Against the Law: Labour Protests in China's Rustbelt and Sunbelt. Berkeley: California University Press.

Madani, S., 2006. The Evolution of Prisoners Rights: From the Constitutional Revolution to the Present Day. Etemad-e Melli, 7 November.

Madsen, M., and Dezalay, Y., 2002. The Power of the Legal Field. In: R. Banakar and M. Travers, eds., Law and Social Theory. Oxford: Hart, pp. 189-204.

Mann, M., 1986. The Autonomous Power of the State: Its Origins, Mechanisms and Results. In: J.A. Hall, ed., States in History. London: Blackwell, pp. 109-136.

Martin, V., 2005. The Qajar Pact: Bargaining, Protest and State in Nineteenth-Century Persia. London: I.B. Tauris.

Matine-Daftary, A., 1930. La Suppression des Capitulations en Perse. Paris: PUF.

Mir-Hosseini, Z., 2008. A Women's Right to Terminate the Marriage Contract: The Case of Iran. In: A. Quraishi and F. Vogel, eds., The Islamic Marriage Contract: Case Studies in Islamic Family Law. Cambridge, MA: Harvard University Press.

Moustafa, T., 2008. Law and Resistance in Authoritarian States: The Judicialization of Politics in Egypt. In: T. Ginsburg and T. Moustafa, eds., Rule by Law: The Politics of Courts in Authoritarian Regimes. New York: Cambridge University Press, pp. 132156.

Mundy, M., and Smith, R.S., 2007. Governing Property, Making the Modern State: Law, Administration and Production in Ottoman Syria. London: I.B. Tauris.

Nachi, M., 2004. The Articulation of "I", "We" and "The Person": Elements for an Anthropological Approach within Western and Islamic Contexts. In: B. Dupret, ed., Standing Trial: Law and the Person in the Modern Middle East. London: I.B. Tauris, pp. 39-66.

Najmabadi, A., 1987. Land Reform and Social Change in Iran. Salt Lake City: University of Utah Press.

Najmabadi, A., 1998. The Story of the Daughters of Quchan: Gender and National Memory in Iranian History. Ney York: Syracuse University Press.

Nayyeri, M., 2012. Iranian Bar Associations: Struggle for Independence. Iran Human Rights Documentation Centre [online], 27 November. Available from:

https://iranhrdc.org/iranian-bar-associations-struggle-for-independence/ [Accessed 8 April 2019].

Poggi, G., 1978. The Development of the Modern State: A Sociological Introduction. Redwood City: Stanford University Press. 
Power, R.W., 1975. Some Comments on Law Related Problems in Iran. Saint Louis University Law Journal, 19, pp. 277-292.

Randjbar-Daemi, S., 2016. Late Pahlavi Narratives on the Constitutional Revolution. In: A.M. Ansari, ed., Iran's Constitutional Revolution of 1906: Narratives of the Enlightenment. London: Gingko Library

Rorty, A.O., ed., 1976. The Identities of Persons. Berkeley: University of California Press.

Rundle, K., 2012. Forms Liberate: Reclaiming the Jurisprudence of Lon Fuller. Oxford: Hart.

Ruthven, M., 2000. Islam: A Very Short Introduction. Oxford University Press.

Saffari, S., 2017. Beyond Shariati: Modernity, Cosmopolitanism and Islam in Iranian Political Thought. New York: Cambridge University Press.

Sait, S., and Lim, H., 2006. Land, Law and Islam. London: Zed Books.

Shapiro, M., 2008. Courts in Authoritarian Regimes. In: T. Ginsburg and T. Moustafa, eds., Rule by Law: Courts in Authoritarian Regimes. New York: Cambridge University Press, pp. 326-336.

Sharabi, H., 1988. Neopatriarchy: A Theory of Distorted Change in Arab Society. New York: Oxford University Press.

Stephenson, M., 2006. A Trojan Horse in China. In: T. Carothers, ed., Promoting the Rule of Law Abroad. Washington, DC: Carnegie University Press, pp. 191-217.

United Nations Office on Drugs and Crime, 2007. Drug and Crime Situation in Iran. Vienna: UNODC.

Vahdat, F., 2015. Reflections on the Iranian Revolution of 1979: The Rise of Subjectivity and Citizenship. Citizenship Studies [online], 19(1), pp. 83-100. Available from: https://doi.org/10.1080/13621025.2015.982963 [Accessed 8 April 2019].

Weiner, M., 2013. The Rule of the Clan: What an Ancient Form of Organisation Reveals about the Future of Individual Freedom. New York: Farrar, Straus and Giroux.

What We Talk about When We Talk about Persons: The Language of a Legal Fiction, 2001. Harvard Law Review [online], 114(6), 1745-1768. Available from: https://doi.org/10.2307/1342652 [Accessed 8 April 2019].

Yamagishi, T., 2018. Individualism, Collectivism, the Rule of Law and General Trust. In: P.A.M. Van Lange, B. Rockenbach and T. Yamagishi, eds., Trust in Social Dilemmas. Oxford University Press.

Zirinsky, M., 2003. Reza Shah's Abrogation of the Capitulations. In: S. Cronin, ed., The Making of Modern Iran: State and Society under Reza Shah 1921-1941. London: Routledge, pp. 81-99.

Zubaida, S., 2003. Law and Power in the Islamic World. London: I.B. Tauris. 